\title{
PENINGKATAN KEMAMPUAN MENULIS NASKAH PIDATO MELALUI MODEL PEMBELAJARAN PELATIHAN KESADARAN (AWARENESS TRAINING) PADA SISWA KELAS X, SMA NEGERI I SUNGGUMINASA KABUPATEN GOWA"
}

\author{
Hasnah Gazali \\ SMA Negeri 1 Sungguminasa Kabupaten Gowa, NIP. 196206051986012004 \\ husni.gazali@gmail.com
}

\begin{abstract}
Abstrak
Adapun tujuan dari penelitian ini adalh untuk mengetahui hasil peningkatan kemampuan siswa menulis naskah pidato dengan model pembelajaran pelatihan kesadaran (Awareness Training). Metode yang digunakan dalam penelitian ini adalah classroom action research atau penelitian tindakan kelas dengan menggunakan dua siklus. Hasil penelitian menunjukkan peningkatkan hasil belajar keterampilan menulis naskah pidato pada siswa kelas $X_{1}$ SMA Negeri I Sungguminasa Kabupaten Gowa. Hal ini ditunjukkan dengan terjadinya peningkatan skor rata-rata hasil belajar dari siklus I 68,26 dengan pencapaian ketuntasan belajar dari siklus I yaitu 57,7\%. Pencapaian ketuntasan belajar meningkat pada siklus II menjadi 84,6\% dan skor rata-rata hasil belajar meningkat pada siklus II menjadi 79,85. Pembelajaran dengan model pelatihan kesadaran (awareness training) sebagian besar dari siswa yang menjadi subjek penelitian merespon secara positif pada siklus I 46,2\% meningkat pada siklus II menjadi $88,4 \%$.
\end{abstract}

Kata Kunci: Menulis, naskah pidato, dan pelatihan kesadaran

\begin{abstract}
The purpose of this study is to know the result of increased ability the students writes speeches with awareness training model. The method used in this research is a classroom action research or action research using two cycles. Results showed improvement of learning outcomes speech writing skills in class X1 SMA Negeri I Sungguminasa Gowa. This demonstrated by the increase in the average score of the first cycle of learning outcomes 68.26 with mastery learning achievement of the first cycle is $57.7 \%$. The achievement of mastery learning increased in the second cycle be $84.6 \%$ and the average score of learning outcomes increased in the second cycle into 79.85. Learning with a training model of consciousness (awareness training) most of the students were the subject of research to respond positively in the first cycle increased $46.2 \%$ in the second cycle becomes $88.4 \%$.
\end{abstract}

Keywords: Writing, speeches, and training awareness

\section{PENDAHULUAN}

Kemajuan belajar dinilai dari kesadaran siswa belajar, bukan hanya melalui hasil. Namun, kebiasaan yang sering dilakukan selama ini oleh sebagian guru untuk mengetahui tingkat pencapaian hasil belajar siswa yaitu hanya melalui tes yang dilaksanakan pada akhir proses pembelajaran. Kemudian tes yang sering dilaksanakan adalah tes tertulis dan lebih mengarah kepada pencapaian kognitif saja, sedangkan untuk mengetahui tingkat pencapaian psikomotorik masih kurang diperhatikan. Siswa lebih banyak dibekali teori dari pada bertindak atau praktik. Padahal, apabila guru menetapkan kompetensi tes perbuatan maka guru dapat meningkatkan hasil belajar siswa. Misalnya, dalam pembelajaran menulis, siswa harus diberi kesempatan sebanyak-banyaknya untuk menulis, seperti: mengarang, menulis naskah pidato, puisi, dan sebagainya.

Berdasarkan hasil observasi yang dilakukan melalui wawancara dengan guru bidang studi bahasa Indonesia khususnya pada siswa kelas $\mathrm{X}_{1}$ SMA Negeri I Sungguminasa Kabupaten Gowa bahwa nilai siswa dalam kemampuan menulis naskah pidato masih rendah dengan nilai rata-rata hasil belajar siswa pada semester genap tahun ajaran 2012/2013 hanya mencapai 65,00 masih di bawah nilai kriteria ketuntasan minimal (KKM) yang telah ditetapkan oleh sekolah tersebut yaitu 70,00 dari skor ideal 100. Melihat realitas yang ada tentang nilai siswa yang masih rendah serta jauh dari standar nilai yang ada, sehingga guru perlu 
sebuah model yang dapat diterapkan supaya hasil belajar siswa meningkat, paling tidak dapat mendekati nilai ketuntasan hasil belajar siswa.

Kondisi kelas $\mathrm{X}_{1}$ SMA Negeri I Sungguminasa Kabupaten Gowa pada saat pembelajaran menulis naskah pidato berlangsung ada beberapa siswa tidak hadir, tidak memerhatikan materi, malas mengajukan pertanyaan, mengabaikan soal latihan, bahkan melakukan kegiatan lain yang tidak relevan dengan pembelajaran. Terkadang ada pula siswa yang ketika diminta menulis naskah pidato masih kesulitan dalam menyusun teks pidato. Selain itu, beberapa di antaranya juga masih kurang percaya diri menuangkan pikirannya dalam kegiatan menulis naskah pidato. Fenomena-fenomena dalam belajar seperti itu sering ditemukan dalam kelas pada saat proses pembelajaran berlangsung. Oleh karena itu, hal semacam ini perlu ditangani secara serius oleh guru-guru agar kemampuan siswa dalam belajar bahasa Indonesia khususnya dalam pembelajaran menulis naskah pidato dapat meningkat pada siswa kelas $\mathrm{X}_{1}$ SMA Negeri I Sungguminasa Kabupaten Gowa.

Kendala tersebut timbul dikarenakan oleh beberapa faktor. Pertama, mata pelajaran bahasa Indonesia oleh sebagian siswa masih dipandang sebagai pelajaran yang tidak menyenangkan dan sangat membosankan. Kedua, siswa kurang aktif dalam pembelajaran yang lebih cenderung menerima saja yang disampaikan oleh guru, lalu diam dan enggan dalam mengemukakan pertanyaan dan pendapat. Hal ini disebabkan karena guru masih cenderung menggunakan model pembelajaran konvensional yaitu suatu model pembelajaran yang banyak didominasi oleh guru, sementara siswa duduk pasif menerima informasi pengetahuan dan keterampilan. Faktor inilah penyebab terhambatnya kreativitas dan kemandirian siswa, sehingga hasil belajar siswa masih rendah. Padahal, sebagai seorang guru profesional, seharusnya memikirkan untuk menggunakan berbagai model pembelajaran yang dapat menekankan keaktifan siswa dalam belajar sehingga penguasaan terhadap materi pelajaran bahasa Indonesia dapat lebih maksimal pada siswa kelas $\mathrm{X}_{1}$ SMA Negeri I Sungguminasa Kabupaten Gowa.

Untuk itu, peneliti bermaksud menerapkan model pembelajaran pelatihan kesadaran (awareness training) untuk menyiasati agar perasaan negatif yang telah tertanam dalam benak siswa yang menyebabkan hasil yang buruk pada pelajaran bahasa Indonesia terutama materi pembelajaran keterampilan menulis naskah pidato bisa menjadi sebuah gairah, rasa senang, suka, ada ketertarikan atau minat yang besar pada pelajaran bahasa Indonesia. Semangat dan kualitas siswa dapat meningkat dalam menulis naskah pidato apabila model pembelajaran pelatihan kesadaran (awareness training) diterapkan dalam proses belajar mengajar.

Kelebihan model pelatihan kesadaran (awareness training) adalah model ini bertujuan untuk meningkatkan pemahaman diri dan kesadaran akan perilaku diri sendiri dan perilaku orang lain sehingga dapat membantu siswa mengembangkan perkembangan pribadi dan sosialnya. Model ini pula tidak memakan waktu terlalu banyak. Dalam pelaksanaan diskusi, keterbukaan dan kejujuran menjadi sangat penting. Hasil penelitian menunjukkan bahwa model ini dapat meningkatkan perkembangan emosi. Sedangkan kekurangan model pelatihan kesadaran adalah dipandang sulit dikaitkan antara prosedur pembelajaran dengan materi yang akan diajarkan sehingga masih sangat sedikit tenaga pendidik yang menerapkan model ini di sekolah.

SMA Negeri I Sungguminasa Kabupaten Gowa pada kelas $\mathrm{X}_{1}$ sebagai lokasi penelitian untuk mengembangkan kemampuan menulis naskah pidato melalui model pembelajaran pelatihan kesadaran karena setelah melakukan observasi di sekolah tersebut peneliti melihat pada penguasaan teori, bukan mengarah pada kemampuan siswa dalam menulis naskah pidato. Selain itu, untuk mengetahui tingkat pencapaian hasil belajar siswa hanya melalui tes yang dilaksanakan pada akhir proses pembelajaran saja tanpa mengarah pada kemampuan siswa. 


\section{TELAAH PUSTAKA}

\section{Keterampilan Menulis}

Ada beberapa bahasan tentang menulis yang dikemukakan oleh para ahli, diantaranya:

"Menulis merupakan salah satu keterampilan berbahasa yang dipergunakan untuk berkomunikasi secara tidak langsung, tidak secara tatap muka dengan orang lain" Tarigan (dalam Munirah: 2007).

"Menulis selalu berurusan dengan bahasa. Hanya bahasalah satu-satunya rumusan untuk menulis itulah sebabnya kecakapan menggunakan bahasa merupakan menjadi bekal utama" Poerwadarminta (dalam Munirah: 2007).

Selanjutnya, "Menulis merupakan suatu bentuk manifestasi kemampuan atau keterampilan berbahasa paling akhir dikuasai pelajar setelah kemampuan mendengarkan, berbicara dan membaca" Nurgiantoro (dalam Munirah: 2007). Kemampuan menulis menghendaki penguasaan berbagai unsur kebahasaan dan unsur di luar bahasa itu sendiri yang akan menjadi isi karangan baik unsur bahasa maupun unsur isi haruslah terjalin rapi untuk menghasilkan karangan yang utuh dan padu.

Menulis adalah salah satu aspek kemampuan berbahasa dan dapat dikuasai oleh siapa saja yang memiliki kemampuan intelektual yang memadai. "Menulis berarti berpikir dengan cara tertentu" D' angelo (dalam Munirah: 2007).

Berdasarkan beberapa pendapat di atas, penulis dapat menyimpulkan bahwa menulis adalah proses berpikir secara tidak langsung dan melahirkan ide, tetapi dalam prosesnya membutuhkan latihan untuk dapat menulis dengan baik.

Menurut Yunus (dalam Munirah 2007:7) "dalam menulis ada tiga fase yang harus diperhatikan, yaitu: (1) fase prapenulisan, (2) fase penulisan, (3) fase pascapenulisan (revisi atau penyempurnaan)".

"Kemampuan menulis merupakan kegiatan yang produktif dan ekspresif" Tarigan (dalam Munirah 2007). Menulis adalah menurunkan simbol-simbol grafis yang menggambarkan suatu bahasa yang dimengerti, sehingga orang lain dapat membaca simbolsimbol grafis itu.

Kemampuan menulis bahasa Indonesia, diartikan sebagai kemampuan dalam menggunakan bahasa Indonesia secara tertulis dalam mengungkapkan diri dan hasil kejiwaannya, menuturkan pengalaman, baik pengalaman penulis maupun pengalaman orang lain, dan memaparkan penghayatan penulis terhadap lingkungan.

\section{Pengertian Pidato}

Pidato dalam Kamus Lengkap Bahasa Indonesia didefinisikan sebagai pengungkapan pikiran dalam bentuk kata-kata yang ditujukan kepada orang banyak; (2) Wacana yang disiapkan untuk diucapkan di depan khalayak

Rapi Tang, dkk. (2008:157) mengemukakan bahwa "pidato merupakan penyampaian dan penanaman pikiran, informasi, atau dari gagasan pembicara kepada khalayak ramai. Seseorang yang berpidato dengan baik akan mampu meyakinkan pendengarnya untuk menerima dan mematuhi pikiran, informasi, gagasan, atau pesan yang disampaikan".

Pidato merupakan penampilan diri seseorang di hadapan pendengar untuk menyampaikan isi hati atau buah pikiran dengan rangkaian kata-kata dengan harapan agar pendengar tergugah hati nuraninya dan tergerak pikirannya. Pidato merupakan bentuk wicara individual yang banyak ragamnya (Muhsin. Muh. Arief, 2016).

Dari beberapa pendapat di atas dapat disimpulkan bahwa pidato adalah suatu kegiatan berbicara di depan umum dengan rangkaian kata yang sistematis untuk mengemukakan pikiran atau gagasan kepada orang banyak agar dapat mereka mengetahui tentang sesuatu hal.

Menulis naskah pidato pada hakikatnya adalah menuangkan gagasan ke dalam bentuk bahasa tertulis yang siap dilisankan melalui kegiatan berpidato. 
Rapi Tang, dkk. (2008:160) mengemukakan bahwa Pidato yang baik ditandai oleh kriteria sebagai berikut:

1. Isinya sesuai dengan kegiatan yang sedang berlangsung,

2. Isinya menggugah dan bermanfaat bagi pendengar,

3. Isinya tidak menimbulkan pertentangan sara,

4. Isinya jelas dan mempunyai tujuan,

5. Isinya benar dan objektif,

6. Bahasa yang digunakan mudah dipahami pendengarnya,

7. Disampai

\section{Model Pembelajaran \\ Kesadaran (Awareness Training)}

Pelatihan

(Tri Mawarningsih: 2012) Model pembelajaran Pelatihan Kesadaran (Awareness Training ) dikembangkan oleh Milliam Schutz. Model ini merupakan suatu model pembelajaran yang ditujukan untuk meningkatkan kesadaran manusia.

Wiliam Schutz menekankan pentingnya pelatihan interpersonal sebagai sarana peningkatan kesadaran pribadi (pemahaman individu).

Mengapa demikian? Karena Ia percaya bahwa ada empat tipe perkembangan yang dibutuhkan untuk merealisasikan potensi individu secara utuh, yakni:

(a) Fungsi tubuh,

(b) Fungsi personal, termasuk di dalamnya akuisisi pengetahuan dan pengalaman, kemampuan berpikir logis dan kreatif dan integrasi intelektual,

(c) Perkembangan interpersonal, dan

(d) Hubungan individu dengan institusiinstitusi sosial, organisasi sosial dan budaya masyarakat.

Schuts ingin mengembangkan model pembelajaran untuk memenuhi salah satu dari keempat tipe perkembangan tersebut, yaitu perkembangan interpersonal. Tujuannya adalah untuk meningkatkan pemahaman diri dan kesadaran akan perilaku diri sendiri dan perilaku orang lain, sehingga dapat membantu siswa untuk mengembangkan perkembangan pribadi dan sosialnya. (B. Uno, Hamzah 2009: 20-21)

\section{METODE PENELITIAN}

\section{A. Jenis Penelitian}

Penelitian ini merupakan penelitian tindakan kelas (classroom action research) yang bertujuan untuk meningkatkan kemampuan menulis naskah pidato pada siswa kelas $\mathrm{X}_{1}$ SMA Negeri I Sungguminasa Kabupaten Gowa melalui model pembelajaran pelatihan kesadaran (awareness training). Secara garis besar pelaksanaan tindakan ini dilakukan minimal dua siklus yang setiap siklus meliputi empat tahapan yaitu perencanaan, pelaksanaan tindakan, observasi dan evaluasi, dan refleksi.

\section{B. Lokasi dan Subjek Penelitian}

Penelitian ini dilaksanakan di kelas $\mathrm{X}_{1}$ SMA Negeri I Sungguminasa Kabupaten Gowa, dengan subjek penelitian sebanyak 25 orang siswa pada semester ganjil tahun pelajaran 2013/2014

\section{Faktor yang Diteliti}

1. Faktor proses, yang akan diselidiki adalah keterlaksanaan proses belajar mengajar yang antara lain kehadiran siswa, perubahan sikap siswa dan keaktifan siswa dalam proses belajar mengajar untuk meningkatkan kemampuan menulis naskah pidato melalui model pembelajaran pelatihan kesadaran (awareness training).

2. Faktor output, yang akan diselidiki adalah hasil belajar siswa dalam menulis naskah pidato yang diperoleh dari tes akhir pada setiap siklus setelah diterapkan model pembelajaran pelatihan kesadaran (awareness training).

\section{Prosedur Penelitian}

Prosedur penelitian ini dirancang atas dua siklus yaitu, siklus pertama (2 minggu) $4 \mathrm{x}$ pertemuan dan, siklus kedua (2 minggu) $4 \mathrm{x}$ pertemuan.

Prosedur penelitian tindakan kelas ini dilaksanakan sesuai dengan perubahan yang ingin dicapai dan pelaksanaanya dilaksanakan menurut prosedur tahapan yaitu, tahap 
perencanaan, tahap pelaksanaan, tahap observasi dan evaluasi, dan tahap refleksi.

\section{E. Instrumen Penelitian}

Instrumen yang digunakan dalam penelitian ini, yaitu lembar observasi dan tes tentang pidato. Observasi digunakan untuk memperoleh data aktivitas guru dan siswa. Tes digunakan untuk memperoleh data kemampuan menulis naskah pidato siswa melalui model pembelajaran pelatihan kesadaran (awareness training) pada siswa kelas $\mathrm{X}_{1}$ SMA Negeri I Sungguminasa Kabupaten Gowa.

\section{HASIL DAN PEMBAHASAN}

\section{A. Deskripsi Hasil Penelitian}

1. Siklus I

a. Tahap Perencanaan

Kegiatan-kegiatan yang dilakukan pada tahap perencanaan ini adalah:

1) Membuat skenario pembelajaran berdasarkan model pembelajaran pelatihan kesadaran untuk pertemuan pertama sampai pertemuan ketiga.

2) Mempersiapkan lembar observasi untuk mencatat aktivitas dan perubahan tingkah laku siswa selama proses pembelajaran berlangsung pada pelaksanaan tindakan siklus I.
3) Mempersiapkan angket respon siswa untuk mengetahui pendapat siswa terhadap tindakan yang dilakukan yang akan diberikan pada akhir siklus I.

4) Mempersiapkan lembar kerja siswa (LKS) yang dikerjakan secara individu pada setiap pertemuan.

5) Mempersiapkan alat evaluasi berupa soal tes siklus I.

6) Mempersiapkan lembar jawaban yang akan digunakan siswa untuk menjawab soal tes siklus I.

b. Tahap Pelaksanaan Tindakan

Adapun pelaksanaan tindakan pada siklus I ini berlangsung selama 4 kali pertemuan dengan lama waktu setiap pertemuan adalah 2 jam pelajaran. Pertemuan I sampai pertemuan III diisi dengan kegiatan belajar mengajar dengan menerapkan model pembelajaran pelatihan kesadaran (awareness training) dan pertemuan IV diisi dengan pemberian tes siklus I, dengan pokok bahasan "Keterampilan Menulis Naskah Pidato".

c. Tahap Observasi dan Evaluasi.

Pada siklus I tercatat aktivitas siswa yang terjadi selama proses pembelajaran berlangsung. Aktivitas tersebut diperoleh dari lembar observasi yang dapat dilihat pada tabel berikut ini.

Tabel 4.1 Hasil Observasi Aktivitas Siswa pada Siklus 1

\begin{tabular}{|c|c|c|c|c|c|c|}
\hline \multirow[t]{2}{*}{ No } & \multirow[t]{2}{*}{ Komponen yang Diamati } & \multicolumn{4}{|c|}{ Siklus I } & \multirow{2}{*}{$\begin{array}{c}\text { Persentase } \\
(\%)\end{array}$} \\
\hline & & I & II & III & IV & \\
\hline \multirow[t]{2}{*}{1} & Siswa yang hadir pada saat proses & 20 & 21 & 23 & \multirow{2}{*}{$\begin{array}{l}\mathrm{T} \\
\mathrm{E} \\
\mathrm{S}\end{array}$} & 82 \\
\hline & pembelajaran berlangsung & & & & & \\
\hline \multirow[t]{4}{*}{2} & Siswa yang mendengarkan atau & 18 & 19 & 20 & \multirow{7}{*}{$\begin{array}{l}\mathrm{S} \\
\mathrm{I} \\
\mathrm{K} \\
\mathrm{L} \\
\mathrm{U} \\
\mathrm{S}\end{array}$} & 73 \\
\hline & memperhatikan penjelasan guru & & & & & \\
\hline & pada saat proses pembelajaran & & & & & \\
\hline & berlangsung & & & & & \\
\hline \multirow[t]{3}{*}{3} & Siswa yang mengajukan pertanyaan & 5 & 11 & 18 & & 43,5 \\
\hline & kepada guru pada saat proses & & & & & \\
\hline & pembelajaran berlangsung & & & & & \\
\hline 4 & $\begin{array}{l}\text { Siswa yang menjawab pertanyaan, } \\
\text { baik dari guru maupun dari siswa } \\
\text { lain pada saat proses pembelajaran }\end{array}$ & 11 & 14 & 17 & $\mathrm{I}$ & 53,8 \\
\hline
\end{tabular}




\begin{tabular}{|c|c|c|c|c|c|}
\hline & berlangsung & & & & \\
\hline 5 & Siswa yang aktif mengerjakan LKS & 18 & 21 & 23 & 79,4 \\
\hline 6 & $\begin{array}{l}\text { Siswa yang melakukan kegiatan lain } \\
\text { (ribut, bermain, tidur dll) pada saat } \\
\text { proses pembelajaran berlangsung }\end{array}$ & 11 & 8 & 5 & 30,7 \\
\hline
\end{tabular}

Berdasarkan tabel 4.1 di atas bahwa terdapat beberapa komponen yang diamati dalam mengobservasi aktivitas siswa pada siklus I di antaranya:

1. Siswa yang hadir pada saat proses pembelajaran berlangsung di pertemuan I siklus I berjumlah 20 siswa, pertemuan II siklus I berjumlah 21 siswa, pertemuan III siklus I berjumlah 23 siswa dan persentase keseluruhannya adalah $82 \%$.

2. Siswa yang mendengarkan atau memperhatikan penjelasan guru pada saat proses pembelajaran berlangsung di pertemuan I siklus I berjumlah 18 siswa, pertemuan II siklus I berjumlah 19 siswa, pertemuan III siklus I berjumlah 20 siswa dan persentase keseluruhannya adalah $73 \%$.

3. Siswa yang mengajukan pertanyaan kepada guru pada saat proses pembelajaran berlangsung di pertemuan I siklus I berjumlah 5 siswa, pertemuan II siklus I berjumlah 11 siswa, pertemuan III siklus I berjumlah 18 siswa dan persentase keseluruhannya adalah $43,5 \%$.

4. Siswa yang menjawab pertanyaan, baik dari guru maupun dari siswa lain pada saat proses pembelajaran berlangsung di pertemuan I siklus I berjumlah 11 siswa, pertemuan II siklus I berjumlah 14 siswa, pertemuan III siklus I berjumlah 17 siswa dan persentase keseluruhannya adalah $53,8 \%$.

5. Siswa yang aktif mengerjakan LKS di pertemuan I siklus I berjumlah 18 siswa, pertemuan II siklus I berjumlah 21 siswa, pertmuan III siklus I berjumlah 23 siswa dan persentase keseluruhannya adalah $79,4 \%$.

6. Siswa yang melakukan kegiatan lain (ribut, bermain, tidur dll) pada saat proses pembelajaran berlangsung di pertemuan I siklus I berjumlah 11 siswa, pertemuan II siklus I berjumlah 8 siswa, pertemuan III siklus I berjumlah 5 siswa dan persentase keseluruhannya adalah $30,7 \%$.

Selanjutnya, pada siklus I ini dilaksanakan tes hasil belajar setelah penyajian materi selama 3 kali pertemuan. Adapun stasistik skor hasil belajar bahasa Indonesia pada siklus 1 dapat dilihat pada tabel 4.2 berikut:

Tabel 4.2 Statistik Skor Hasil Belajar Bahasa Indonesia Siswa Kelas $X_{1}$ SMA Negeri I Sungguminasa Kabupaten Gowa pada Siklus I

\begin{tabular}{ccc}
\hline No & Statistik & Nilai \\
\hline 1 & Subjek & 26 \\
\hline 2 & Skor Ideal & 100 \\
\hline 3 & Skor Maksimum & 80 \\
\hline 4 & Skor Minimum & 50 \\
\hline 5 & Rentang Skor & 30 \\
\hline 6 & Skor Rata-Rata & 68,26 \\
\hline 7 & Standar Deviasi & 9,37 \\
\hline
\end{tabular}

Berdasarkan tabel 4.2 di atas bahwa subjek yang diteliti adalah 26, skor ideal yang diharapkan adalah 100, skor maksimum yang dicapai adalah 80, skor minimum yang dicapai 
adalah 50, rentang skornya adalah 30 , skor ratarata yang telah dicapai adalah 68,26 dan standar deviasinya adalah 9,37 .

Jika skor hasil belajar bahasa Indonesia pada siklus I dikelompokkan ke dalam lima kategori, maka diperoleh distribusi frekuensi dan persentase skor seperti disajikan pada tabel 4.3 berikut:

Tabel 4.3 Distribusi Frekuensi dan Persentase Skor Hasil Belajar Bahasa Indonesia Siswa Kelas $\mathrm{X}_{1}$ SMA Negeri I Sungguminasa Kabupaten Gowa pada Siklus I

\begin{tabular}{cccc}
\hline Skor & Kategori & Frekuensi & Persentase (\%) \\
\hline $0-54$ & Sangat rendah & 3 & 11,6 \\
$55-64$ & Rendah & 4 & 15,4 \\
$65-79$ & Sedang & 15 & 57,7 \\
$80-89$ & Tinggi & 4 & 15,3 \\
$90-100$ & Sangat tinggi & 0 & 0 \\
\hline \multicolumn{7}{c}{ Jumlah } & 26 & 100 \\
\hline
\end{tabular}

Berdasarkan tabel 4.3, di atas dapat dinyatakan bahwa dari 26 siswa yang menjadi subjek penelitian, 3 siswa yang berada pada kategori sangat rendah, 4 siswa yang berada pada kategori rendah, 15 siswa yang berada pada kategori sedang, 4 siswa yang berada pada kategori tinggi, dan 0 siswa yang berada pada kategori sangat tinggi.

Apabila hasil belajar pada siklus I dianalisis, maka persentase ketuntasan belajar siswa pada siklus I dapat dilihat pada tabel 4.4 berikut:

Tabel 4.4 Deskripsi Ketuntasan Belajar Siswa Kelas X ${ }_{1}$ SMA Negeri I Sungguminasa Kabupaten Gowa pada Siklus I

\begin{tabular}{|c|c|c|c|}
\hline Skor & Kategori & Frekuensi & Persentase (\%) \\
\hline $0-69$ & Tidak tuntas & 11 & 42,3 \\
\hline $70-100$ & Tuntas & 15 & 57,7 \\
\hline
\end{tabular}

Berdasarkan tabel 4.4 di atas bahwa siswa yang berada pada kategori tidak tuntas sebanyak 11 siswa dengan persentase 42,3\%, sedangkan siswa yang berada pada kategori tuntas sebanyak 15 siswa dengan persentase $57,7 \%$.

Selanjutnya respon siswa terhadap pembelajaran yang telah diterapkan pada siklus 1 dapat dilihat pada tabel berikut:

Tabel 4.5 Data Respon Siswa pada Siklus I

\begin{tabular}{cccccc}
\hline & & \multicolumn{2}{c}{$\begin{array}{c}\text { Frekuensi } \\
\text { Respon Siswa }\end{array}$} & \multicolumn{2}{c}{ Persentase (\%) } \\
\cline { 3 - 6 } NO & Aspek yang Direspon & $\begin{array}{c}\text { Positif } \\
\text { (ya) }\end{array}$ & $\begin{array}{c}\text { Negatif } \\
\text { (Tidak) }\end{array}$ & $\begin{array}{c}\text { Positif } \\
(\mathbf{y a})\end{array}$ & $\begin{array}{c}\text { Negatif } \\
\text { (Tidak) }\end{array}$ \\
\hline 1. & Apakah Anda suka belajar bahasa & 11 & 15 & 42,3 & 57,6 \\
\hline 2. & Andonesia? & 13 & 13 & 50 & 50 \\
\hline
\end{tabular}




\begin{tabular}{|c|c|c|c|c|c|}
\hline & $\begin{array}{c}\text { Indonesia dengan model } \\
\text { pembelajaran pelatihan kesadaran } \\
\text { (awareness training)? }\end{array}$ & & & & \\
\hline 3. & $\begin{array}{c}\text { Apakah pembelajaran dengan } \\
\text { model pembelajaran pelatihan } \\
\text { kesadaran (awareness training) } \\
\text { menjadikan Anda siswa yang aktif } \\
\text { dan kreatif? }\end{array}$ & 12 & 14 & 46,2 & 53,8 \\
\hline 4. & $\begin{array}{c}\text { Apakah pembelajaran dengan } \\
\text { model pembelajaran pelatihan } \\
\text { kesadaran (awareness training) } \\
\text { cocok digunakan untuk belajar } \\
\text { bahasa Indonesia? }\end{array}$ & 12 & 14 & 46,2 & 53,8 \\
\hline 5. & $\begin{array}{l}\text { Apakah Anda senang dengan cara } \\
\text { guru Anda menyampaikan pelajaran } \\
\text { dengan model pembelajaran } \\
\text { pelatihan kesadaran (awareness } \\
\text { training)? }\end{array}$ & 12 & 14 & 46,2 & 53,8 \\
\hline 6. & $\begin{array}{l}\text { Apakah Anda merasa ada perubahan } \\
\text { pada diri Anda setelah diterapkan } \\
\text { pembelajaran dengan model } \\
\text { pembelajaran pelatihan kesadaran } \\
\text { (awareness training)dalam belajar } \\
\text { bahasa Indonesia? }\end{array}$ & 9 & 17 & 34,6 & 65,3 \\
\hline 7. & $\begin{array}{l}\text { Apakah Anda termotivasi untuk } \\
\text { belajar setelah diterapkan } \\
\text { pembelajaran dengan model } \\
\text { pembelajaran pelatihan kesadaran } \\
\text { (awareness training)? }\end{array}$ & 8 & 16 & 30,7 & 61,5 \\
\hline 8. & $\begin{array}{c}\text { Apakah Anda senang dengan } \\
\text { pemberian tugas? }\end{array}$ & 15 & 11 & 57,7 & 42,3 \\
\hline 9. & $\begin{array}{c}\text { Apakah Anda senang dengan } \\
\text { pemberian tes atau evaluasi setiap } \\
\text { akhir siklus? }\end{array}$ & 18 & 8 & 69,2 & 30,7 \\
\hline 10. & $\begin{array}{c}\text { Apakah sebelumnya Anda sudah } \\
\text { pernah mendapatkan pembelajaran } \\
\text { seperti ini di kelas? }\end{array}$ & 0 & 26 & 0 & 100 \\
\hline
\end{tabular}

d. Refleksi

1) Umumnya siswa menunjukkan antusias belajar yang positif, seperti menanggapi pertanyaan, keberanian mengajukan pertanyaan atau tanggapan pada guru, dan keinginan untuk menyelesaikan LKS. Namun karena siswa belum terbiasa dengan tindakan yang diberikan maka kelas menjadi agak gaduh sehingga pengelolaan kelas lebih ditekankan pada siklus II.

2) Masih ada beberapa siswa yang sulit dalam menyelesaikan LKS berkomunikasi dengan teman kelompoknya. Untuk itu guru harus membimbing siswa tersebut.

3) Dari hasil tes siklus 1, masih terdapat beberapa siswa yang mendapatkan nilai di bawah KKM. Hal ini disebabkan karena dalam kegiatan pembelajaran selama 3 
pertemuan sebelumnya, beberapa siswa tersebut kurang aktif dalam pembelajaran, tidak memperhatikan penjelasan, dan tidak hadir dalam beberapa pertemuan.

e. Keputusan

Hasil belajar siswa pada siklus I belum mencapai indikator keberhasilan yang telah ditetapkan yaitu tuntas individu jika memperoleh skor rata-rata $70 \mathrm{ke}$ atas, sehingga pelaksanaan tindakan masih dilanjutkan pada siklus II dengan berbagai perbaikan berdasarkan pada refleksi pada siklus I.

\section{Siklus II}

a. Tahap Perencanaan

Kegiatan-kegiatan yang dilakukan pada tahap perencanaan ini adalah:

1) Membuat skenario pembelajaran berdasarkan model pelatihan kesadaran untuk pertemuan pertama sampai pertemuan ketiga. Dimana skenario pembelajaran ini sedikit berbeda dengan siklus I yakni penggunaan alat peraga lebih ditekankan untuk menghindari kegaduhan di kelas serta komunikasi antara guru dan siswa lebih lancar sehingga materi lebih mudah dipahami dan dapat meningkatkan hasil belajar yang diperoleh.

2) Mempersiapkan lembar observasi untuk mencatat aktivitas dan perubahan tingkah laku siswa selama belajar mengajar berlangsung pada pelaksanaan tindakan siklus II.
3) Mempersiapkan angket respon siswa untuk mengetahui pendapat siswa terhadap tindakan yang dilakukan, yang akan diberikan pada akhir siklus II.

4) Mempersiapkan lembar kerja siswa (LKS) yang dikerjakan secara individu pada setiap pertemuan.

5) Mempersiapkan alat evalusi berupa soal tes siklus II.

6) Mempersiapkan lembar jawaban yang akan digunakan siswa untuk menjawab soal tes siklus II.

b. Tahap Pelaksanaan Tindakan

Adapun pelaksanaan tindakan pada siklus II ini berlangsung selama 4 kali pertemuan dengan lama waktu setiap pertemuan adalah 2 jam pelajaran. Pertemuan I sampai pertemuan III diisi dengan kegiatan belajar mengajar dengan menerapkan model pembelajaran pelatihan kesadaran (awareness training) dan pertemuan IV diisi dengan pemberian tes siklus I, dengan pokok bahasan "Keterampilan Menulis Naskah Pidato"

c. Tahap Observasi dan Evaluasi.

Pada siklus II tercatat aktivitas siswa yang terjadi selama proses pembelajaran berlangsung. Aktivitas tersebut diperoleh dari lembar observasi yang dapat dilihat pada tabel berikut ini.

Tabel 4.6 Hasil Observasi Aktivitas Siswa pada Siklus II

\begin{tabular}{|c|c|c|c|c|c|c|}
\hline \multirow[t]{2}{*}{ No } & \multirow[t]{2}{*}{ Komponen yang Diamati } & \multicolumn{4}{|c|}{ Siklus II } & \multirow{2}{*}{$\begin{array}{c}\text { Persentase } \\
(\%)\end{array}$} \\
\hline & & I & II & III & IV & \\
\hline 1 & $\begin{array}{l}\text { Siswa yang hadir pada saat proses } \\
\text { pembelajaran berlangsung }\end{array}$ & 21 & 25 & 26 & $\begin{array}{l}\mathrm{T} \\
\mathrm{E}\end{array}$ & 92,2 \\
\hline 2 & $\begin{array}{l}\text { Siswa yang mendengarkan atau } \\
\text { memperhatikan penjelasan guru pada } \\
\text { saat proses pembelajaran berlangsung }\end{array}$ & 19 & 24 & 26 & $S$ & 88,4 \\
\hline 3 & $\begin{array}{l}\text { Siswa yang mengajukan pertanyaan } \\
\text { kepada guru pada saat proses } \\
\text { pembelajaran berlangsung }\end{array}$ & 10 & 15 & 20 & $\begin{array}{l}\mathrm{I} \\
\mathrm{K} \\
\mathrm{L}\end{array}$ & 57,6 \\
\hline 4 & $\begin{array}{l}\text { Siswa yang menjawab pertanyaan, baik } \\
\text { dari guru maupun dari siswa lain pada } \\
\text { saat proses pembelajaran berlangsung }\end{array}$ & 11 & 14 & 18 & $\begin{array}{l}\mathrm{U} \\
\mathrm{S}\end{array}$ & 55,1 \\
\hline 5 & Siswa yang aktif mengerjakan LKS & 20 & 25 & 25 & II & 89,7 \\
\hline
\end{tabular}




$\begin{array}{lllllll}6 & \text { Siswa yang melakukan kegiatan lain } 4 & 3 & 2 & 11,4 \\ \text { (ribut, bermain, tidur dll) pada saat } \\ \text { proses pembelajaran berlangsung }\end{array}$

Berdasarkan tabel 4.7 di atas bahwa terdapat beberapa komponen yang diamati dalam mengobservasi aktivitas siswa pada siklus II, di antaranya:

1. Siswa yang hadir pada saat proses pembelajaran berlangsung di pertemuan I siklus II berjumlah 21 siswa, pertemuan II siklus II berjumlah 25 siswa, pertmuan III siklus II berjumlah 26 siswa dan persentase keseluruhannya adalah $92,2 \%$.

2. Siswa yang mendengarkan atau memperhatikan penjelasan guru pada saat proses pembelajaran berlangsung di pertemuan I siklus II berjumlah 19 siswa, pertemuan II siklus II berjumlah 24 siswa, pertemuan III siklus II berjumlah 26 siswa dan persentase keseluruhannya adalah $88,4 \%$.

3. Siswa yang mengajukan pertanyaan kepada guru pada saat proses pembelajaran berlangsung di pertemuan I siklus II berjumlah 10 siswa, pertemuan II siklus II berjumlah 15 siswa, pertemuan III siklus II berjumlah 20 siswa dan persentase keseluruhannya adalah $57,6 \%$.
4. Siswa yang menjawab pertanyaan, baik dari guru maupun dari siswa lain pada saat proses pembelajaran berlangsung di pertemuan I siklus II berjumlah 11 siswa, pertemuan II siklus II berjumlah 14 siswa, pertemuan III siklus II berjumlah 18 siswa dan persentase keseluruhannya adalah $55,1 \%$.

5. Siswa yang aktif mengerjakan LKS di pertemuan I siklus II berjumlah 20 siswa, pertemuan II siklus II berjumlah 25 siswa, pertemuan III siklus II berjumlah 25 siswa dan persentase keseluruhannya adalah $89,7 \%$.

6. Siswa yang melakukan kegiatan lain (ribut, bermain, tidur, dll) pada saat prose pembelajaran berlangsung di pertemuan I siklus II berjumlah 4 siswa, pertemuan II siklus II berjumlah 3 siswa, pertemuan III siklus II berjumlah 2 siswa dan persentase keseluruhannya adalah $11,5 \%$.

Selanjutnya, pada siklus ini juga dilaksanakan tes hasil belajar seperti pada siklus 1. Adapun data skor hasil belajar pada siklus II dapat dilihat pada table berikut:

Tabel 4.7 Statistik Skor Hasil Belajar Bahasa Indonesia Siswa Kelas $X_{1}$ SMA Negeri I Sungguminasa Kabupaten Gowa pada Siklus II.

\begin{tabular}{ccc}
\hline No & Statistik & Nilai \\
\hline 1 & Subjek & 26 \\
\hline 2 & Skor Ideal & 100 \\
\hline 3 & Skor Maksimum & 95 \\
\hline 4 & Skor Minimum & 65 \\
\hline 5 & Rentang Skor & 30 \\
\hline 6 & Skor Rata-Rata & 79,8 \\
\hline 7 & Standar Deviasi & 10,24 \\
\hline
\end{tabular}

Berdasarkan tabel 4.8 di atas bahwa subjek yang diteliti adalah 26, skor ideal yang diharapkan adalah 100, skor maksimum yang dicapai adalah 95, skor minimumnya adalah 65 , rentang skornya adalah 30 , skor rata-rata yang dicapai adalah 79,8, dan standar deviasinya adalah 10,24.

Jika skor hasil belajar bahasa Indonesia tersebut dikelompokkan ke dalam lima kategori, maka diperoleh distribusi frekuensi dan 
persentase seperti disajikan pada tabel 4.8 berikut:

Tabel 4.8 Distribusi Frekuensi dan Persentase Hasil Belajar Bahasa Indonesia Siswa Kelas $\mathrm{X}_{1}$ SMA Negeri I Sungguminasa Kabupaten Gowa pada Siklus II.

\begin{tabular}{cccc}
\hline Skor & Kategori & Frekuensi & Persentase (\%) \\
\hline $0-54$ & Sangat rendah & 0 & 0 \\
$55-64$ & Rendah & 0 & 0 \\
$65-79$ & Sedang & 13 & 50 \\
$80-89$ & Tinggi & 5 & 19,2 \\
$90-100$ & Sangat tinggi & 8 & 30,7 \\
\hline
\end{tabular}

Jumlah $26 \quad 100$

Berdasarkan tabel 4.9 di atas dapat kategori tinggi, dan 8 siswa yang berada pada dinyatakan bahwa dari 26 siswa yang menjadi subjek penelitian, 0 siswa yang berada pada kategori sangat rendah, 0 siswa yang berada pada kategori rendah, 13 siswa yang berada pada kategori sedang, 5 siswa yang berada pada kategori sangat tinggi.

Apabila hasil belajar pada siklus II dianalisis, maka persentase ketuntasan belajar siswa pada siklus I dapat dilihat pada tabel 4.9 berikut:

Tabel 4.9 Deskripsi Ketuntasan Belajar Siswa Kelas $X_{1}$ SMA Negeri I Sungguminasa Kabupaten Gowa pada Siklus II

\begin{tabular}{|c|c|c|c|}
\hline Skor & Kategori & Frekuensi & Persentase $(\%)$ \\
\hline $0-69$ & Tidak tuntas & 4 & 15,4 \\
\hline $70-100$ & Tuntas & 22 & 84,6 \\
\hline \multicolumn{2}{|c|}{ Jumlah } & 26 & 100 \\
\hline
\end{tabular}

Berdasarkan tabel $4.10 \mathrm{di}$ atas bahwa siswa yang berada pada kategori tidak tuntas berjumlah 4 siswa dengan persentase $15,4 \%$, sedangkan siswa yang berada pada kategori tuntas berjumlah 22 siswa dengan persentase $84,6 \%$.

Selanjutnya respon siswa terhadap pembelajaran yang telah diterapkan pada siklus II dapat dilihat pada tabel berikut:

Tabel 4.10 Data Respon Siswa pada Siklus II

\begin{tabular}{|c|c|c|c|c|c|}
\hline \multirow{2}{*}{ NO } & \multirow{2}{*}{ Aspek yang Direspon } & \multicolumn{2}{|c|}{$\begin{array}{c}\text { Frekuensi Respon } \\
\text { Siswa }\end{array}$} & \multicolumn{2}{|c|}{ Persentase (\%) } \\
\hline & & $\begin{array}{c}\text { Positif } \\
\text { (ya) }\end{array}$ & $\begin{array}{l}\text { Negatif } \\
\text { (Tidak) }\end{array}$ & $\begin{array}{c}\text { Positif } \\
\text { (ya) }\end{array}$ & $\begin{array}{l}\text { Negatif } \\
\text { (Tidak) }\end{array}$ \\
\hline 1. & $\begin{array}{l}\text { Apakah Anda suka belajar bahasa } \\
\text { Indonesia? }\end{array}$ & 18 & 8 & 69,2 & 30,7 \\
\hline 2. & $\begin{array}{l}\text { Apakah Anda suka belajar bahasa } \\
\text { Indonesia dengan model } \\
\text { pembelajaran pelatihan kesadaran } \\
\text { (awareness training)? }\end{array}$ & 15 & 11 & 57,6 & 42,3 \\
\hline 3. & $\begin{array}{c}\text { Apakah pembelajaran dengan } \\
\text { model pembelajaran pelatihan } \\
\text { kesadaran (awareness training) } \\
\text { menjadikan Anda siswa yang aktif } \\
\text { dan kreatif? }\end{array}$ & 22 & 4 & 88,4 & 11,5 \\
\hline
\end{tabular}




\begin{tabular}{|c|c|c|c|c|c|}
\hline 4. & $\begin{array}{c}\text { Apakah pembelajaran dengan } \\
\text { model pembelajaran pelatihan } \\
\text { kesadaran (awareness training) } \\
\text { cocok digunakan untuk belajar } \\
\text { bahasa Indonesia? }\end{array}$ & 23 & 3 & 88,4 & 11,5 \\
\hline 5. & $\begin{array}{l}\text { Apakah Anda senang dengan cara } \\
\text { guru anda menyampaikan } \\
\text { pelajaran dengan model } \\
\text { pembelajaran pelatihan kesadaran } \\
\text { (awareness training)? }\end{array}$ & 24 & 2 & 96,1 & 7,6 \\
\hline 6. & $\begin{array}{l}\text { Apakah Anda merasa ada } \\
\text { perubahan pada diri anda setelah } \\
\text { diterapkan pembelajaran dengan } \\
\text { model pembelajaran pelatihan } \\
\text { kesadaran (awareness } \\
\text { training)dalam belajar bahasa } \\
\text { Indonesia? }\end{array}$ & 21 & 5 & 80,7 & 19,2 \\
\hline 7. & $\begin{array}{l}\text { Apakah Anda termotivasi untuk } \\
\text { belajar setelah diterapkan } \\
\text { pembelajaran dengan model } \\
\text { pembelajaran pelatihan kesadaran } \\
\text { (awareness training)? }\end{array}$ & 23 & 3 & 88,4 & 11,5 \\
\hline 8. & $\begin{array}{c}\text { Apakah Anda senang dengan } \\
\text { pemberian tugas? }\end{array}$ & 19 & 7 & 73 & 26,9 \\
\hline 9. & $\begin{array}{c}\text { Apakah Anda senang dengan } \\
\text { pemberian tes atau evaluasi setiap } \\
\text { akhir siklus? }\end{array}$ & 22 & 4 & 84,6 & 15,3 \\
\hline 10. & $\begin{array}{l}\text { Apakah sebelumnya Anda sudah } \\
\text { pernah mendapatkan } \\
\text { pembelajaran seperti ini di kelas? }\end{array}$ & 26 & 0 & 100 & 0 \\
\hline
\end{tabular}

Upaya yang dilakukan untuk meningkatkan kemampuan menulis naskah pidato pada siswa kelas $\mathrm{X}_{1}$ SMA Negeri $\mathrm{I}$ Sungguminasa Kabupaten Gowa melalui model pembelajaran pelatihan kesadaran, guru selaku peneliti tidak terlepas dari perhatian dan perubahan sikap siswa dalam proses pembelajaran. Hal ini dapat dilihat pada lembar observasi yang dilakukan selama pelaksanaan tindakan.

Kegiatan siswa pada siklus II ini, semangat dan perhatian siswa dalam proses pembelajaran meningkat. Hal ini tampak dari perhatian siswa dalam memperhatikan materi dan siswa yang mengajukan pertanyaan. Pada saat guru memantau siswa dalam mempelajari materi pada umumnya aktif. Selain itu, siswa yang melakukan kegiatan yang tidak relevan dengan pembelajaran mengalami penurunan.

Berdasarakan hasil observasi yang mempengaruhi semangat belajar meningkat, yaitu: (1) Guru memberikan penguatan dan memberikan motivasi pada siswa, (2) guru mengubah struktur dan variasi kelompok yaitu dengan memasukkan satu atau lebih tutor yang bisa membimbing teman kelompoknya agar setiap siswa mampu menulis naskah pidato serta tampil berpidato dengan baik di depan umum, (3) guru menampilkan media yang menarik sesuai dengan konteks dan kebiasaan anak, (4) guru memberikan penilaian secara proporsional terhadap tugas yang dikerjakan oleh siswa. 


\section{KESIMPULAN DAN SARAN}

\section{A. Simpulan}

Pembelajaran dengan penerapan model pelatihan kesadaran (awareness training) dapat meningkatkan hasil belajar keterampilan menulis naskah pidato pada siswa kelas $X_{1}$ SMA Negeri I Sungguminasa Kabupaten Gowa. Hal ini ditunjukkan dengan terjadinya peningkatan skor rata-rata hasil belajar dari siklus I 68,26 dengan pencapaian ketuntasan belajar dari siklus I yaitu $57,7 \%$. Pencapaian ketuntasan belajar meningkat pada siklus II menjadi $84,6 \%$ dan skor rata-rata hasil belajar meningkat pada siklus II menjadi 79,85 . Pembelajaran dengan model pelatihan kesadaran (awareness training) sebagian besar dari siswa yang menjadi subjek penelitian merespon secara positif pada siklus I $46,2 \%$ meningkat pada siklus II menjadi $88,4 \%$.

Penerapan model pembelajaran pelatihan kesadaran (awareness training) berdasarkan lembar observasi aktifitas siswa terjadi peningkatan dari siklus I ke siklus II. Hal ini dilihat dari kehadiran siswa pada siklus I $82 \%$ meningkat pada siklus II menjadi 92,2\%, keaktifan dalam memperhatikan materi yang dijelaskan oleh guru dari siklus I 73\% meningkat pada siklus II menjadi $88,4 \%$, siswa yang mengajukkan pertanyaan dari siklus I $43,5 \%$ meningkat pada siklus II menjadi $57,6 \%$, siswa yang aktif menjawab pertanyaan dari siklus I $53,8 \%$ meningkat pada siklus II menjadi 55,1\%, dan siswa yang aktif mengerjakan LKS dari siklus I 79,4\% meningkat pada siklus II menjadi $89,7 \%$.

\section{B. Saran}

Hendaknya pendidik mampu menggunakan model sesuai dengan materi yang diajarkan dan kondisi siswa, guru juga dituntut untuk dapat menerapkan model pembelajaran dengan benar.

Orang tua hendaknya memperhatikan pendidikan anaknya dan memberikan motivasi untuk belajar agar dapat meningkatkan prestasi anaknya sehingga apa yang diharapkan oleh orang tua dan guru dapat tercapai yakni keberhasilan siswa.

Pemerintah hendaknya lebih memperhatikan sekolah yang betul-betul membutuhkan bantuan khususnya yang menyangkut tentang pegembangan profesionalisme guru agar melahirkan siswa yang berkualitas.

\section{DAFTAR PUSTAKA}

B. Uno, Hamzah. 2009. Model Pembelajaran: Menciptakan Proses Belajar Mengajar yang Kreatif dan Efektif. Jakarta: Bumi Aksara.

Chulsum, Umi dan Windi Novia. 2006. Kamus Besar Bahasa Indonesia. Surabaya: Kashiko.

Cisca. 2011. Ejaan Yang Disempurnakan. Yogyakarta. Cabe Rawit.

Darmawati. 2010. "Peningkatan Keterampilan Menulis Karangan Narasi Siswa Kelas V SDN No. 9 Makkaraeng Kabupaten Maros Melalui Metode Pemberian Tugas". Skripsi. FKIP Unismuh Makassar.

Hamdani. 2011. Strategi Belajar Mengajar. Bandung: Pustaka setia.

Munirah. 2006. Dasar Keterampilan Menulis. Makassar: Unismuh Makassar.

Paizaluddin dan Ermalinda. 2013. Penelitian Tindakan Kelas. Bandung: Alfabeta.

Rakhmat, Jalaludin. 1982. Retorika Modern. Bandung: Akademika.

Rapi Tang, Muhammad, dkk. 2008. Pengembangan Kepribadian Bahasa Indonesia. Makassar: Universitas Negeri Makassar.

Tanti Yuniar. Kamus Lengkap Bahasa Indonesia. Jakarta: Agung Media Mulia. 
Aurigamaulana. 2012. Definisi Pidato. Terdapat pada: blogspot.com /2012/05/definisipidato-jenis-tujuan-metode. $\mathrm{html}$. Diakses pada tanggal 30 Juni 2013.

Edukasi Net. 2010. Jenis Pidato.Terdapat Pada: http://edukasi.net/index.php?mod=script \&cmd=Bahan\%20Belajar/Materi\%20Po kok/view\&id=531\&uniq $=4710$. Diakses pada tanggal 12 Juni 2013.

Hertanti Pratiwi. 2010. "Analisis Kemampuan Menulis Naskah Pidato Siswa kelas XI SMK YPKK 1 Sleman Yogyakarta". Skripsi. FKIP Universitas Sanata Dharma Yogyakarta.

Kompasiana. 2012. Keterampilan menulis. Terdapat pada: http://bahasa.kompasiana.com/2012/03/ 25/hakikat-keterampilan-menulis449101.html. Diakses pada tanggal 29 Juni 2013.

Muhammad Satriawan. 2012. Kelompok model pembelajaran personal (personal family). Terdapat pada: http://muhammadsatriawan27.blogspot.c om/2012/09/kelompok-modelpembelajaran-personal.html. Diakses pada tanggal 03 Juli 2013.

Muhsin, Muh. Arief. 2016 . The Effectiveness of Positive Feedback in Teaching Speaking Skill. Lingua Cultura, 10(1), 25-30. http://dx.doi.org/10.21512/lc.v10i1.873

Tri Mawarningsih. 2012. Awareness Training (Pelatihan Kesadaran). Terdapat pada: http://nhingz-

anwar.blogspot.com/2012/11/awarenesstraining-pelatihan-kesadaran.html. Diakses pada tanggal 01Juni 2013.

Sugianto. 2011. Pidato. Terdapat pada: http://sugikmaut.blog.com/?p=22. Di Akses pada tanggal 12 Mei 2012.

Sulaiman, Tohirah. 2011. "Peningkatan Kemampuan Belajar Sosiologi Melalui Metode Problem Besid Learning pada Siswa Kelas X SMA Negeri 1 Flores".
Skripsi. Makassar: FKIP Unismuh Makassar. 